\title{
US fusion researchers brace for major cuts
}

Washington. As widely anticipated, the US Congress has made deep cuts in fusion research, renewable energy research and money for technology transfer from the Department of Energy laboratories to industry, in a broad appropriations bill for spending on energy and water which was agreed last week.

The bill - one of the thirteen currently moving through Congress which President Bill Clinton is expected to sign without further argument - sets the budget for the Department of Energy's non-nuclear weapons work for the 1996 financial year, which began on 1 October.

The research programme most severely affected by the bill will be magnetic fusion, whose budget falls from $\$ 375$ million last year to $\$ 244$ million. This cut marks a historic shift, say fusion researchers, with the United States dropping a 40-year quest for a working fusion power plan to concentrate instead on a slimmed-down effort on basic research into fusion.

The \$244-million fusion budget $-\$ 15$ million more than proposed by the House of
Representatives, but $\$ 32$ million less than the Senate wanted - will leave the three main US fusion research facilities scrambling for funds, and the future of US participation in the International Thermonuclear Experimental Reactor (ITER) hanging in the balance (see Nature 377, 567; 1995).

Anne Davies, the director of the Department of Energy's fusion programme, says she has "no idea" which facilities will continue to run, but promises to decide "within a week or so". She says that the outright closure of one or more facilities will "have to be looked at", and that the "theory and university programmes will be cut too much, and the technology programme just wiped out" by the budget.

Asked about ITER, she says: "I'm sympathetic to ITER but the problems are so bad at all the institutions - we have to figure out a way to do it that the community will not feel to be lop-sided."

The main domestic fusion facilities are the Tokamak Fusion Test Reactor (TFTR) at Princeton, New Jersey, costing $\$ 70$ million a year to run; General Atomics' DIII-D experiment in San Diego, California, which costs about $\$ 50$ million; and the Alcator CMOD machine at the Massachusetts Institute of Technology, which costs $\$ 16$ million.

TFTR and DIII-D have not been operating since the beginning of the financial year, pending the budget decision. Tom Simonen, director of DIII-D, says he hopes it will get some money from the "extra" \$15 million to run for eight weeks in the coming year. But, he adds dryly, "there are a lot of demands on that $\$ 15$ million".

Also hit hard by the appropriations bill are renewable energy research programmes, which will get $\$ 280$ million, down from $\$ 388$ million this year. Support for technology transfer from the three weapons laboratories falls from $\$ 225$ million to $\$ 160$ million and from the non-defence laboratories from $\$ 35$ million to $\$ 20$ million.

The main physics programmes of the Department of Energy will receive small increases in funding, and $\$ 100$ million will be provided for a Special Facilities Initiative to improve the use of physics equipment.

Colin Macilwain

\section{Chernomyrdin promises 'significant increase' for science}

Moscow. Viktor Chernomyrdin, the Russian prime minister, promised last week that the government would propose a significant increase in funding for science in its draft budget for next year. At the same time, he called for a major overhaul of Russian science, one of whose objectives would be to eliminate inefficient laboratories "and perhaps even whole institutes".

Speaking at a meeting at the Joint Institute for Nuclear Research (JINR) in Dubna, Chernomyrdin also promised that the government would try to find funds for Russian physicists to participate in the construction of the Large Hadron Collider at the European Laboratory for Particle Physics (CERN).

The prime minister said that the precise figure for next year's science budget is being debated within the government and that it is already clear that the sum will be "significantly higher" than this year's figure.

At the same time, he stressed that there also needs to be more support from industry and the banking sector, and suggested that this should have been encouraged by the recent stabilization of the country's economy. As an example, he announced that the Dubna institute, the Promradtekhbank commercial bank and several Dubna-based military enterprises plan to set up a research and development investment fund to mount joint projects.

Chernomyrdin also said that the legal status and viability of the Dubna institute one of Russia's leading research institutions
- needs to be preserved, particularly in the light of its recent difficulties (see Nature 367, 208; 1994) and promised to provide the funds to allow this to happen.

According to Viktor Mikhaylov, Russia's atomic energy minister, a new agreement with the institute commits the government to regular payment of its annual contribu-

IMAGE
UNAVAILABLE
FOR
COPYRIGHT
REASONS

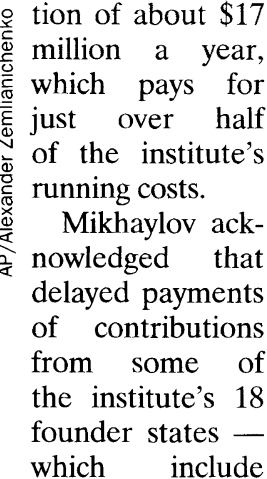

Chernomyrdin: pledged higher science budget.

which include

East European and former Soviet countries, Cuba, North Korea, Mongolia and China had meant that some important research programmes had been halted.

Chernomyrdin's promise of extra funding came shortly after a meeting in Moscow organized jointly by the Organisation for Economic Cooperation and Development (OECD), the lower chamber (Duma) of the Russian Parliament and the Ministry for Science and Technological Policy, the third such meeting over the past two years.

Andrei Fonotov, co-chairman of the seminar and deputy minister of science, told the meeting that, with elections due in two months time, probably leading to a change of government, it was important that decisions are taken soon on issues facing parliament, enabling achievements to be passed on to whoever takes office in the future.

"We are preparing the drafts of all laws related to scientific activity, constantly trying to coordinate them with ministries and state committees, which sometimes block our efforts for months," said Fonotov. In some cases, even after the government had agreed on a joint policy, parliament had not found time to discuss it; and one of the few laws recently adopted by the parliament - on genetic engineering - has not yet been signed by President Boris Yeltsin on the ground that it is "too declarative".

Mikhail Glubokovsky, deputy chairman of the Duma Committee on Culture, Education and Science - and as such responsible for the science budget - told the meeting that funding for science should be increased at least threefold. "But it will never be done by this government, this parliament and this president," he said.

Glubokovsky produced figures to show that the funding of science in Russia has fallen from 1.03 per cent of GNP (or 3.87 per cent of state budget expenditure) in 1991 to 0.44 and 2.19 per cent respectively last year. The 1995 figure proposed by the government would reduce this still further to 0.34 per cent of GNP, while the Duma had approved a slightly higher target of 0.38 per cent.

Carl Levitin 